\title{
MEMOIR
}

\section{JOHN GOWANS PARKER}

THE sudden and unexpected death of John G. Parker on 4 November 1953 removed from life insurance business on the American continent one of its most distinguished and highly regarded members. At the time of his passing he had been actively associated with The Imperial Life Assurance Company of Canada for more than forty-seven years.

One of a family of ten, John Parker was botn on 6 September $188_{3}$ in Haldimand County, Ontario, where his father was the County Registrar. Proximity to the Grand River gave him a taste for canoeing - his favourite sport in his earlier years. His other athletic interest, when he went to the University of Toronto at the age of 17 to complete his formal education, was the gymnasium team of which he was a member.

It was in 1904, when Parker graduated from the University as a Gold Medalist in Mathematics, that he was invited by the late G. Cecil Moore to come and help The Imperial Life in the preparation of some mortality tables. In those days Moore was Associate Actuary of the Company, Thomas Bradshaw being Actuary. But $\$ 25.00$ monthly (the remuneration for actuarial juniors in those days) seemed rather small compensation, so for two years Parker returned to the University to lecture as a Fellow in Mathematics. The life insurance business proved irresistible, however, and in 1906 he returned to The Imperial Life as a member of the permanent staff. Apart from that short period with the University he spent his entire business life in the service of The Imperial Life and life insurance business at large.

His outstanding ability was recognized by steady promotion from his position as a clerk in the Actuarial Department through the posts of Assistant Actuary, Associate Actuary, Actuary, General Manager and Actuary, and Managing Director, until he became President in 1947. On I October 1953, as he had planned for some time to do, he resigned the Presidency of the Company, following which the Board of Directors elected him as their Chairman. It was a matter of the keenest regret to the Board that Parker's illness at the time of his election to the Chairmanship and his death a few weeks thereafter had permitted him to act only once in his new capacity.

Over the years, even in his very early days on the staff, Parker was one of the key figures in the growth and progress of his Company. Primarily an actuary, he was equally at home in the other fields of the Company's operations and particularly the agency field, with which he had maintained a close and intimate contact throughout the years.

His record as an actuary was unique. He was the only man ever to have been elected President of both the constituent bodies of the present Society of Actuaries, namely, the Actuarial Society of America and the American Institute of Actuaries. It was as President of the American Institute of Actuaries that he attended the International Congress of Actuaries in London in 1927, following which he received his Honorary Fellowship of the Institute of Actuaries. At the time of his death he was Canadian correspondent of the Institute of Actuaries, also Vice-President for Canada and national correspondent of the Permanent Committee of International Congresses of Actuaries. To all in the actuarial field 
Jack Parker, as he was familiarly known, was the warm friend and wise counsellor, regardless of Company affiliations.

Parker was President of the Life Insurance Institute of Canada in 1937-38 and President of the Canadian Life Insurance Officers Association in 1942-43. With the last organization he was engaged in a great deal of committee work that has had far-reaching effect on life insurance business in Canada. In 1926, for instance, the joint committee consisting of representatives of the Life Underwriters Association of Canada, the then Canadian Association of Life Agency Officers and the Canadian Life Insurance Officers Association was appointed. This Committee did much to promote a feeling among life underwriters of all companies that there was a common meeting-place where their representatives had an opportunity to discuss their problems with representatives of other associations in the business. It also took an active part in developing the principles governing agency matters and in sponsoring legislation in many provinces of Canada respecting the licensing of agents. For many years be was Chairman of this Committee.

During the early years of the recent war he was the first Chairman of the War Problems Committee of the Canacian Life Insurance Officers Association. This task was undertaken when a host of new problems arose concerning the use of war clauses and related underwriting problems. The calibre of Parker was such that whenever and wherever the going was difficult he was called upon, and his willing assumption of leadership in the affairs of the Life Officers Association through the years did much to strengthen the joint endeavours of the companies. With such a background it was particularly appropriate that, when he was introduced as a speaker at the Association's 6oth Annual Meeting in May 1953, he was referred to as 'Mr Life Insurance'-a designation by which he will continue to be known. He had come to epitomize life insurance business and all it stands for in the eyes of his confreres.

A man of great energy, and with a deep sense of responsibility to his church, his country, his community and the business in which he was engaged, it was inevitable that his career should be marked by distinguished service both in communal and business life. Merely to touch on a few of his activities is to indicate the broad nature of the services he rendered: Member, United Church Board of Finance; Member, Board of Managers of Deer Park United Church in Toronto; Chairman of World War II Victory Loan Campaigns in Toronto from the Third Campaign to the end of the War; Honorary Treasurer of Local Community Chests; Director of the Consumers' Gas Company, of Canada Permanent Trust Company, and of the Canadian Reinsurance Company.

Those of us who had the good fortune to know John Parker will always remember him as a warm and approachable executive, an inspiring leader and a man of great energy. In his death not only his Company, but the entire life insurance industry, has suffered a great loss.

G. W. B. 